\title{
31. TEPHRA FROM DEEP SEA DRILLING PROJECT LEG 66: MIDDLE AMERICA TRENCH TRANSECT (SOUTHERN MEXICO) ${ }^{1}$
}

\author{
J. P. Cadet, Y. Thisse, and A. Pouclet, Département des Sciences de la Terre, \\ Université d'Orléans, 45046 Orléans, France \\ J. M. Bardintzeff, Laboratoire de Pétrographie, Volcanologie, Université de Paris Sud, 91405 Orsay, France \\ and \\ J. F. Stephan, Université de Bretagne Occidentale, 29283 Brest Cedex, France
}

\section{INTRODUCTION}

Deep Sea Drilling Project Leg 66 drilled eight sites along a transect across the Middle America Trench off Mexico, including continental (Sites 493 and 489), oceanic (Site 487), and trench (Site 486) reference sites and four sites $(490,492,491,488)$ in the trench inner wall (Fig. 1; Moore et al., 1979a, 1979b). Because of their location-close to volcanic sources and subject to prevailing winds and marine currents ( $\mathrm{N}$ to $\mathrm{S}$, NW to $\mathrm{SE}$ - analysis of airborne ashes intercalated within the sediments at these sites (Fig. 2) provides a reliable record of explosive volcanism in the area.

Intense onshore volcanic activity in Mexico during the Oligo-Miocene has been well documented (Demant, 1978; Gastil et al., 1979; McDowell and Clabaugh, 1979) by the andesites and ignimbrites of the Sierra Madre Occidental and Sierra Madre del Sur and in the Plio-Quaternary by the andesites and basalts from the Trans-Mexican Neovolcanic Belt and the eastern border of Baja California.

\section{ASH AT LEG 66 SITES (Fig. 3)}

\section{Continental References Sites}

Site 493 includes three holes drilled in 645 meters of water about $25 \mathrm{~km}$ from the Mexican mainland. Sediments above basement document four hiatuses. Quaternary, Pliocene, and upper Miocene muds and muddy silts contain only ash spots, but about 20 thin ash or tuff layers, often devitrified, are interbedded in lower Miocene muddy siltstone. Colored volcanic glass is quite frequent in this unit (Table 1).

Site 489 is located on the upper slope of the Middle America Trench. Only Quaternary and lower Miocene muddy siltstones were found in cores. Quaternary and the finer-grained upper parts of the lower Miocene contain discrete ash layers.

\section{Trench Inner Wall Sites}

Site 490 is situated on the seaward edge of the transition zone between the presumed accretionary zone and continental crust. Quaternary muds are devoid of ash, but Pliocene muddy siltstones contain thin ash and

\footnotetext{
${ }^{1}$ Initial Reports of the Deep Sea Drilling Project, Volume 66.
}

vitric beds, vitric silts (10-30\% volcanic glass), and some thick ( 25 and $35 \mathrm{~cm}$ ) light to dark gray ash layers (Table 1). The rest of the drilled series (Pliocene?-upper Miocene) is similar in sedimentary characteristics and contains thin ash beds, intensely fractured.

Site 492 is located on the inner wall midslope. Quaternary to upper Miocene hemipelagic silt and muddy siltstone are sporadically interbedded with ash layers that are sometimes gassy, frozen, graded, up to $38 \mathrm{~cm}$ thick and with ash pods. Upper Miocene turbidites (fine sand to granular gravel interbedded with muddy siltstone) which represent either lower slope or trench deposit do not show evidence of volcanism.

Site 491 is located in the midslope of the inner wall, about $14 \mathrm{~km}$ landward of the Middle America Trench. Minor thin lenses (1 mm to $2 \mathrm{~cm}$ ) of ash occur in Quaternary and Pliocene silty muds. Lower Pliocene muddy siltstone interbedded with fine to coarse pebbly sand is the result of too turbulent a deposition to allow the deposit of ashes layers.

Site 488 in located on the lower slope of the Middle America Trench. Sediments consist of Quaternary mud and mudstone with local thin silt and muddy sand beds in the lower portion, probably accumulated in a turbidity channel. Ash layers are infrequent and restricted to the upper Quaternary; disseminated volcanic glass, very abundant on top, decreases rapidly downsection.

\section{Trench Site}

Site 486 is in a small sediment pond (representative of the discontinuous filling of the Middle America Trench). The stratigraphic section cored consists of muddy and coarse sands of Quaternary age (Table 1).

\section{Ocean Reference Site}

Site 487 is located on the oceanic plate about $11 \mathrm{~km}$ seaward of the Middle America Trench. Pleistocene and uppermost Pliocene hemipelagic mud contains light gray ash layers up to $11 \mathrm{~cm}$ thick, ash pods, and volcanic glass in minor amounts throughout most of the section (Table 1). Pliocene to upper Miocene brown pelagic clay which overlies basalt includes two thin ash beds and some ash lumps.

\section{Sedimentary Environment}

We theorize that ash layers are derived mainly from deposition of volcanic particles transported primarily by 


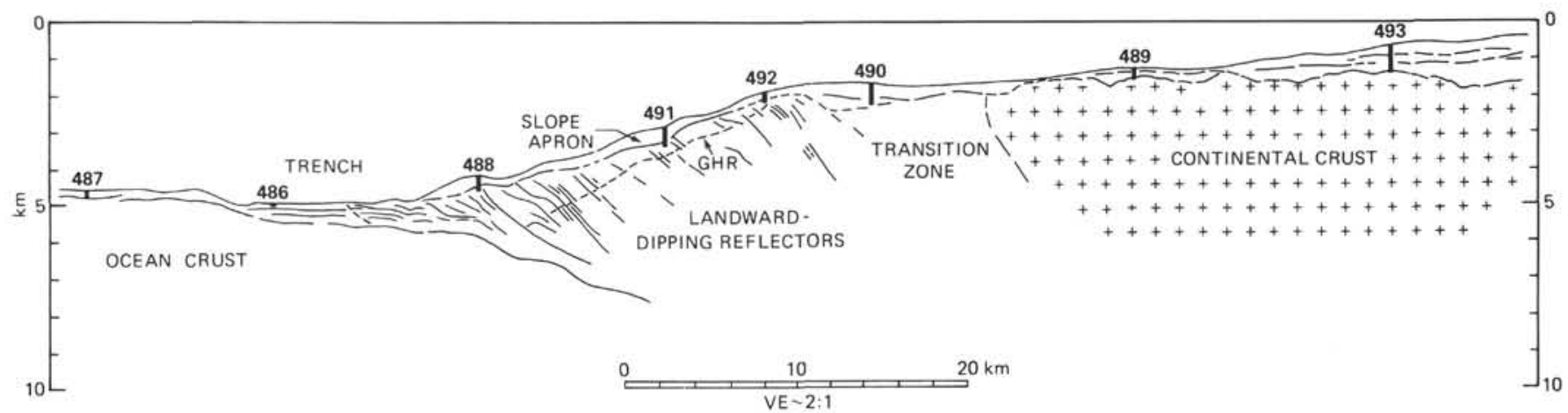

Figure 1. Schematic transect of Leg 66 showing location of sites (after Moore et al., 1979a).

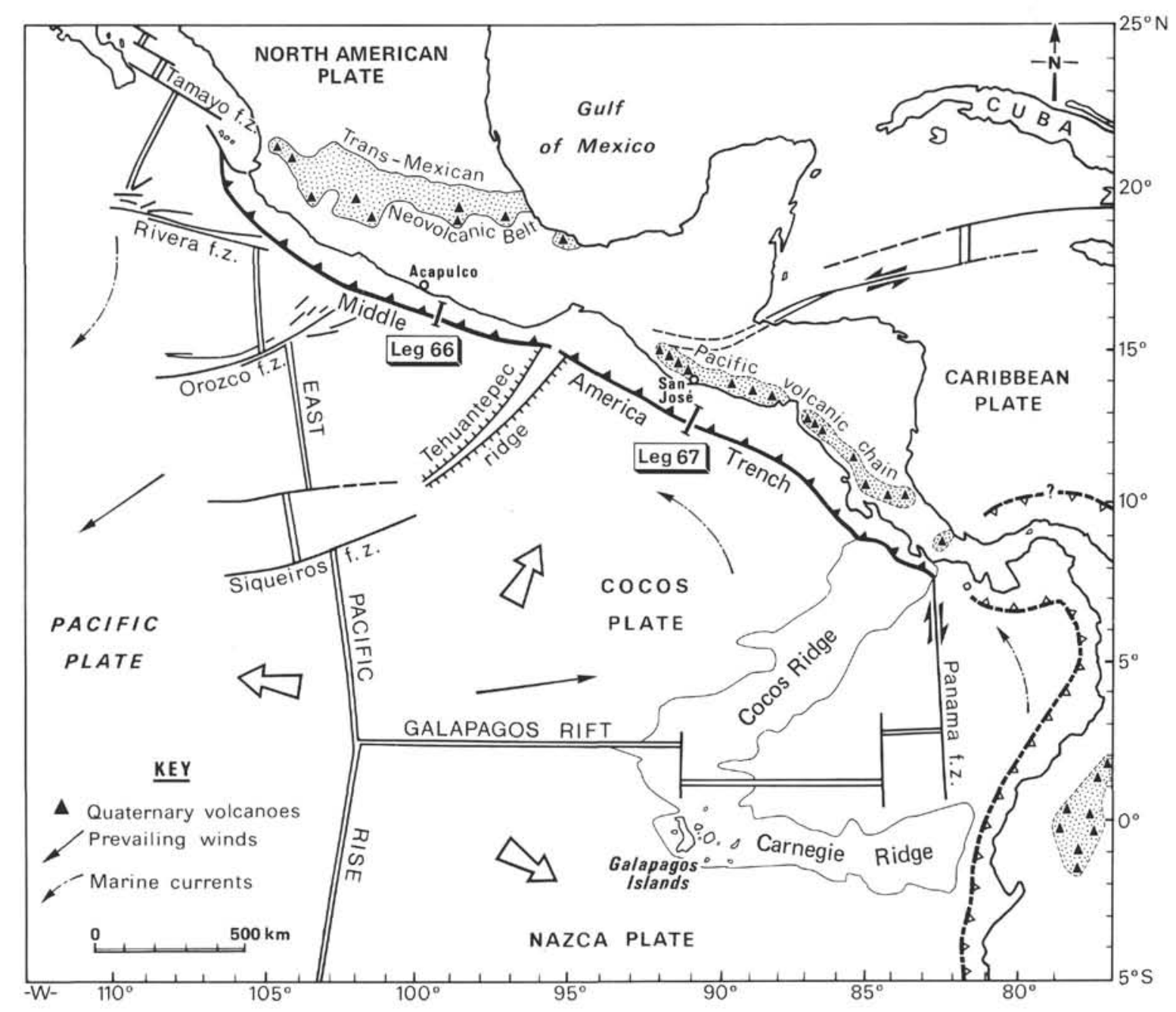

Figure 2. Geologic setting of Leg 66.

air currents which settle through the water column and are redeposited by either weak turbidity or bottom currents. In order to identify individual ash layers, it is necessary that surrounding sediment not be too coarse.

At the continental sites $(493,489$, and 490$)$ sedimentary sequences of hemipelagic muds and mudstones and terrigenous material are limited to the lower Miocene. At slope sites, recent slope and slope basin deposits are free from coarse sands and are principally hemi- pelagic. Turbiditic sediments are common in Recent deposits as we near the trench, in the middle upper Miocene at Site 492, in the lower Pliocene at Site 491, and in the lower Quaternary at Site 488. In the trench itself, the Quaternary is represented by turbiditic sands. Thus data on explosive volcanism will be less and less complete with proximity of the sites to the trench.

Although the pelagic and hemipelagic sedimentation in the oceanic site (487) is favorable to a good record of 


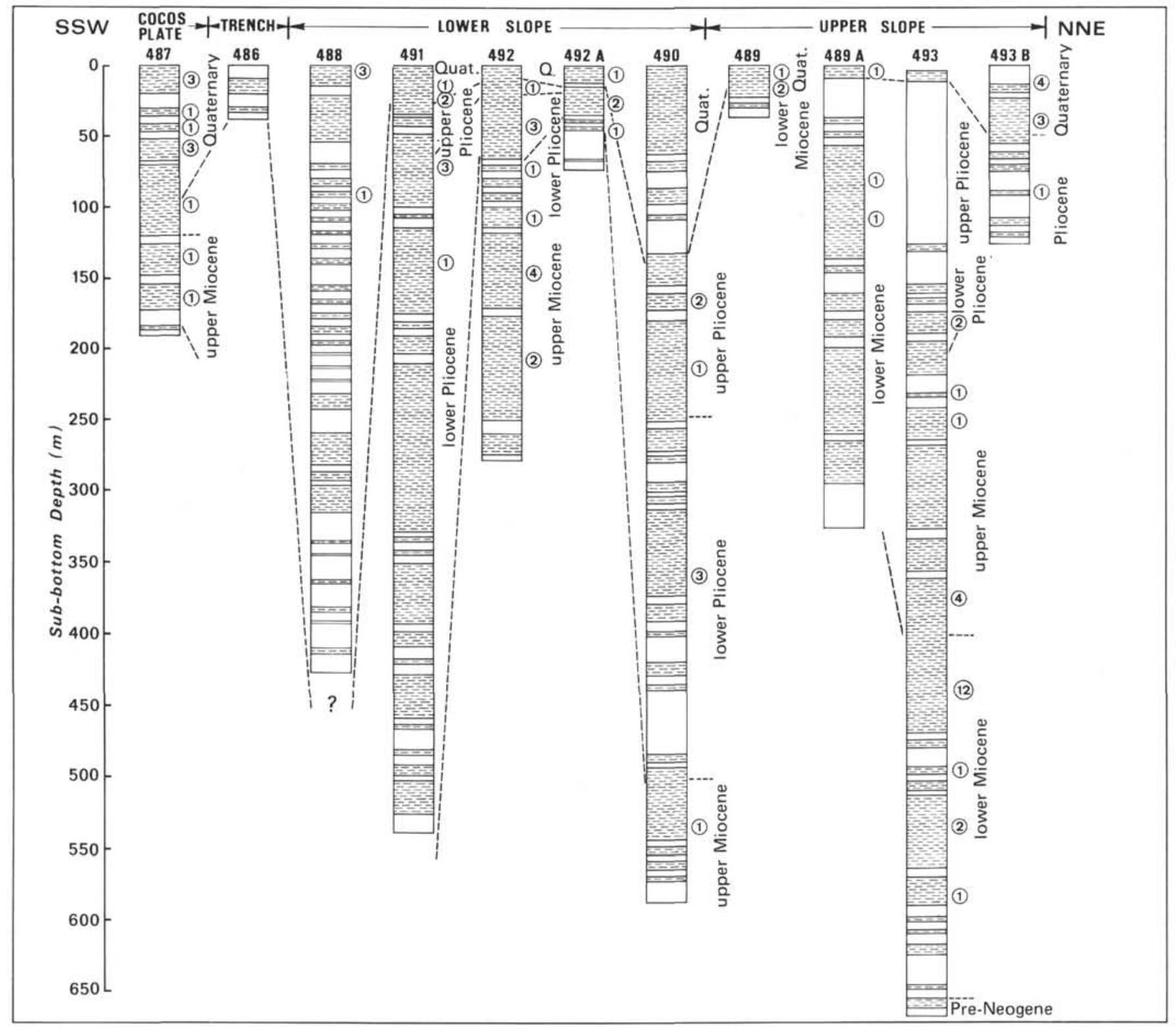

Figure 3. Recovery at Leg 66 sites (circled numbers are the number of ash layers in the recovered sediments).

ash deposition, distance from the volcanic source becomes a predominant factor.

\section{GEOCHEMISTRY AND MINERALOGY OF LEG 66 ASHES}

We sampled 16 ash layers for chemical analysis. They derive from all the sites and date from the Holocene to the lower Miocene (Table 2). They include glass shards, micropumice, and mineral fragments and were classically prepared by sieving, ultrasonic washing, etc. They were analyzed with a BRGM/CNRS electron probe microanalyzer CAMEBAX (accelerating voltage $15 \mathrm{kV}$, sample current $0.02 \mu \mathrm{A}$, defocalized beam, average diameter $10-20 \mu \mathrm{m}, 10$-s count time).

\section{Glass Analysis}

We performed 47 chemical analyses of glass shards for which the sum of oxides (major elements) is between
91.5 and 95 . This systematic deficit, without visible alteration, can be attributed to hydration, according to Scheidegger et al. (1978) and Fujioka et al. (1980). This phenomenon, independent of the age and location of samples, seems to occur rapidly during pyroclastic deposition.

\section{Composition}

All glasses are acidic and dacitic to rhyolitic $\left(\mathrm{SiO}_{2}\right.$ : 68-76\%; average $\mathrm{SiO}_{2}: 73.43$; standard deviation: 1.87 ). Table 3 presents 22 analyses.

Using the classical diagrams for $\mathrm{SiO}_{2} /$ alkaline (Fig. 4) and $\mathrm{SiO}_{2} / \mathrm{K}_{2} \mathrm{O}$ (Fig. 5), chemical analyses show double spreading for silica and alkalines. The causes of geochemical variation are submarine alteration after deposition, magmatic differentiation, and diversity of volcanic material. Because all samples are roughly the same in grain size and because there is no geochemical cor- 


\section{J. P. CADET ET AL.}

Table 1. Smear slides (contents in \%).

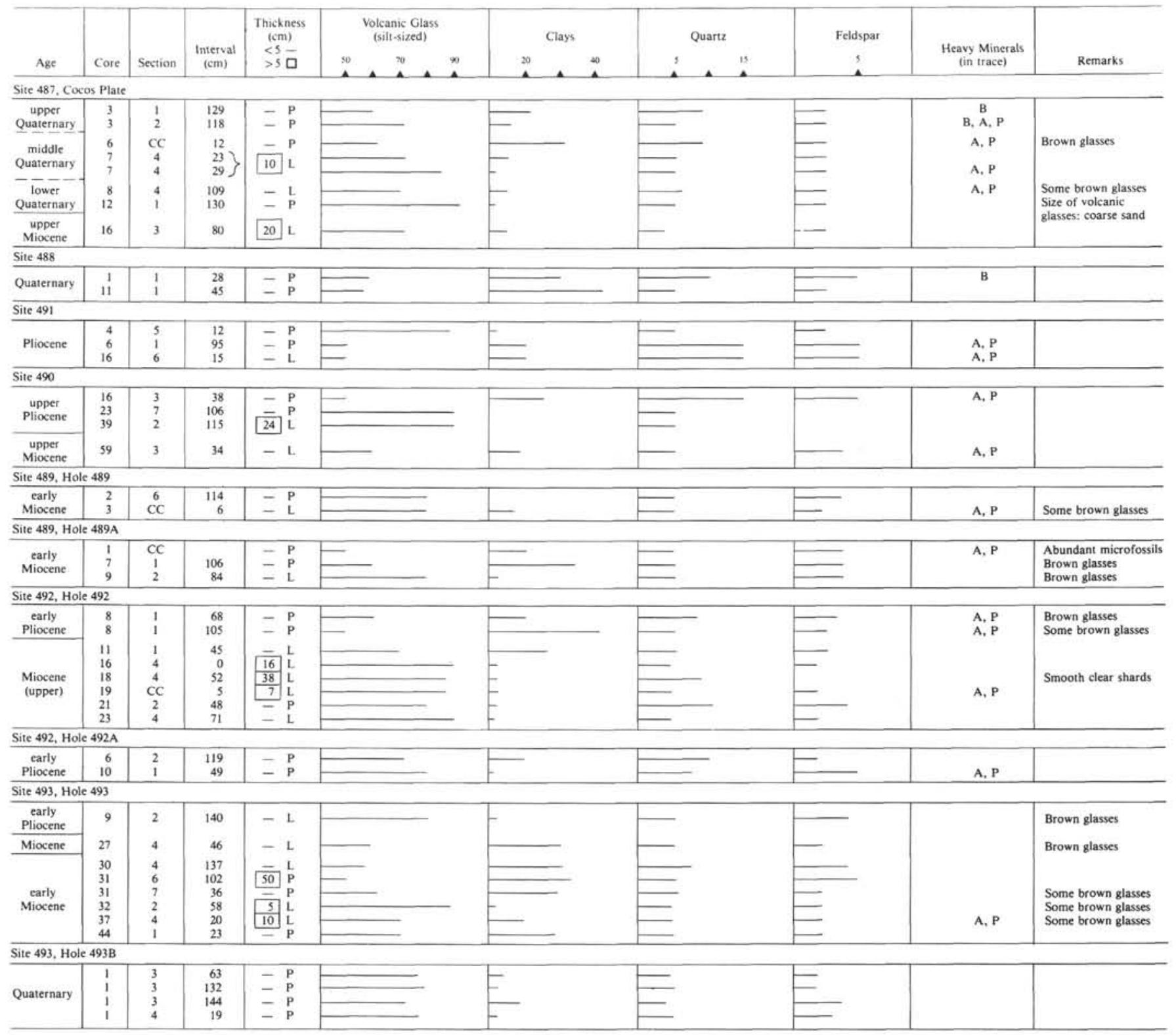

Note: $\mathrm{L}=$ layer, $\mathrm{P}=$ pocket, $\mathrm{A}=$ amphibole, $\mathrm{B}=$ biotite, $\mathrm{P}=$ pyroxene.

relation between the age of volcanism and, for example, variation in alkaline content, eventual alteration should be a minor factor of variability.

Positive correlation silica/alkalines seems to be linked to magmatic differentiation from dacites to rhyolites; we use the typologic boundaries of Pecerillo and Taylor (1976) in Figure 5, with a supplementary category of rhyo-dacites $\left(\mathrm{SiO}_{2}\right.$ between 70 and $\left.72 \%\right)$. On an AFM diagram (Fig. 6) the dots follow the trends of acidic differentiation, and it is not possible to observe the nature (tholeiitic, calc-alkaline, etc.) of the magmatic series. On the $\mathrm{SiO}_{2} / \mathrm{K}_{2} \mathrm{O}$ diagram, on the other hand, chemical analysis shows trends similar to calc-alkaline series with medium potassium content.

The differentiation index (D.I. of Thornton and Tuttle, 1960) varies from 69 to 86 . The negative correlation silica/alkalines, and the important variations of $\mathrm{K}_{2} \mathrm{O}$ for products of similar D.I. in particular, may result from the presence of several magmatic types issuing from different volcanoes (we discount the analytical method and alteration as main factors). Accordingly, we classify components in three main groups: $A=$ low potassium, $\mathrm{B}=$ medium potassium, and $\mathrm{C}=$ high potassium. Average limits for $68 \% \mathrm{SiO}_{2}$ are $\mathrm{A}-\mathrm{B}=1.75$ $\mathrm{K}_{2} \mathrm{O}$ and $\mathrm{B}-\mathrm{C}=2.50 \mathrm{~K}_{2} \mathrm{O}$. For $72 \% \mathrm{SiO}_{2}$ they are A-B $=2 \mathrm{~K}_{2} \mathrm{O}$, and $\mathrm{B}-\mathrm{C}=3 \mathrm{~K}_{2} \mathrm{O}$. For $75 \% \mathrm{SiO}_{2}, \mathrm{~A}-\mathrm{B}=2.25$ $\mathrm{K}_{2} \mathrm{O}$ and $\mathrm{B}-\mathrm{C}=3.50 \mathrm{~K}_{2}$ (cf. Fig. 5).

This preliminary study is limited by the small number of data. Still, a statistical investigation of the principal component analysis (in preparation) confirms the meaning of the first two factors of chemical variations: (1) for magmatic differentiation, opposition between silica 
Table 2. Location and number of analysis of glass shards and feldspars.

\begin{tabular}{|c|c|c|c|c|}
\hline $\begin{array}{c}\text { Sample } \\
\text { (interval in } \mathrm{cm} \text { ) }\end{array}$ & $\begin{array}{l}\text { Glass } \\
\text { Shards }\end{array}$ & Feldspars & Age & Group \\
\hline 493B-1-3 (132-134) & 1 & 1 & Present & 1 \\
\hline $493 \mathrm{~B}-1-4(19-21)$ & 2 & 1 & & \\
\hline 487-3-1 (129-130) & 4 & & upper & 2 \\
\hline $487-7-4(23-25)$ & 4 & & Pleistocene & \\
\hline $487-8-4(109-110)$ & 4 & & & \\
\hline $491-4-5(12-13)$ & 2 & 3 & lower Pleistocene & 3 \\
\hline $491-6-1$ (95-96) & 2 & & upper & \\
\hline $492 \mathrm{~A}-6-2(119-120)$ & 3 & 3 & Pliocene & 3 \\
\hline $490-23-7(106)$ & & 4 & & \\
\hline $490-39-2(115-117)$ & 3 & & lower & 4 \\
\hline $493-9-2(140-142)$ & 3 & & Pliocene & \\
\hline $492-11-1(45-46)$ & 1 & 1 & & \\
\hline $492-16-4(0-2)$ & 2 & & upper & \\
\hline $492-18-4(52-53)$ & 3 & & Miocene & \\
\hline $492-21-2(49-50)$ & 3 & & & 5 \\
\hline $492-23-4(72-74)$ & 3 & & & \\
\hline $487-16-3(80-81)$ & 2 & & & \\
\hline $493-32-2(58-60)$ & 4 & & middle Miocene & 6 \\
\hline 489A-9-2 (84-85) & 3 & & lower Miocene & 6 \\
\hline
\end{tabular}

and other elements ( $60 \%$ of the variance); (2) for serial distinction, opposition between alkalines-mainly potassium-and other elements ( $17 \%$ of the variance).

\section{Chronological Evolution}

Initial sorting of products into three groups allows us to follow the evolution of magmatic types in the different sites:

early Miocene (continental Sites 489 and 493): appearance of medium-potassic rhyolites (a little less differentiated at Site 493)

late Miocene: the same products appear (upper slope Site 492 and oceanic Site 487), coexisting with high potassic-rhyolites and high-potassic dacites (Site 492)

Pliocene: only medium-potassic rhyolites and rhyodacites

late-Pleistocene: low-potassic rhyolites, very differentiated medium-potassic rhyolites, and, possibly, high-potassic rhyolites (oceanic Site 487)

Present: medium-potassic rhyolites (Site 489)
This evolution is schematized in Figure 7 , in which samples showing a negative correlation $\mathrm{SiO}_{2} / \mathrm{K}_{2} \mathrm{O}$ are associated by age groups and by the $\mathrm{A}, \mathrm{B}$, and $\mathrm{C}$ classification. Despite the scarcity of data, we notice the permanence of a moderately potassic volcanic activity. A few more potassic products occur in the lower Miocene(?), upper Miocene, and upper Pleistocene; some low potassic products occur in the upper Pleistocene.

\section{Mineral Analysis}

Mineral fragments (15 feldspars and 2 amphiboles) among the glass shards were analyzed with electron probe microanalyzer. They come from different sites and have various ages (Table 2). The chemical composition of feldspar is shown in Table 4 and Figure 8. There are 2 sanidines, 3 albites, 9 plagioclases ranging from $\mathrm{An}_{20}$ to $\mathrm{An}_{50}$, and one anorthite $\mathrm{An}_{90}$, which may be fragments of zoned phenocrysts. Alkaline feldspars and acidic plagioclases are associated with medium-potassic rhyolites; the two intermediate plagioclases $\left(\mathrm{An}_{40-50}\right)$ are linked with present dacites. These minerals could come from the same lava as the glassy shards which surround them. The two amphiboles (unknown age) are common hornblende (Table 5). They may belong to calc-alkaline volcanic lavas.

\section{DISTRIBUTION OF ASH LAYERS AND EXPLOSIVE VOLCANISM RECORD}

\section{METHODS}

We assume that the record of explosive volcanic activity on land can be read, with certain limitations, in the distribution of ash layers. Many studies deal with the interpretation of ash occurrence in DSDP cores, analyzing and displaying the data (see a partial review in Cadet and Fujioka, 1980).

In the present chapter we take into account all the ash layers, even the minor ones, as well as pods if, after checking the smear slides, we can determine that the glass content is above $60 \%$ and that the amount of reworked material is low, thus allowing us reasonably to assume that the pods are related to a single ash layer. We then plot the number of ash layers versus time by dividing the sediment section into intervals of $1 \times 10^{6}$ years, using sedimentation accumulation curves, estimating the number of ash layers in this interval, and adjusting for the degree of core recovery (Hein et al., 1978; Cadet and Fujioka, 1980).

Table 3. Chemical analysis and norms of glass shards.

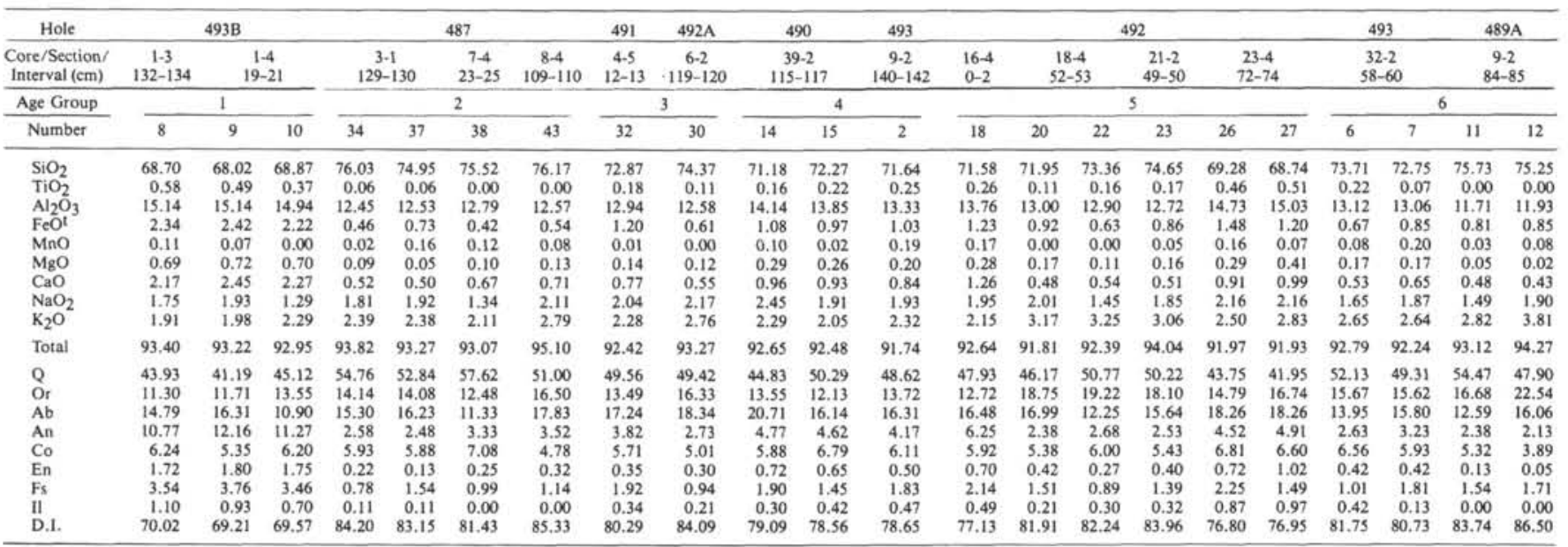




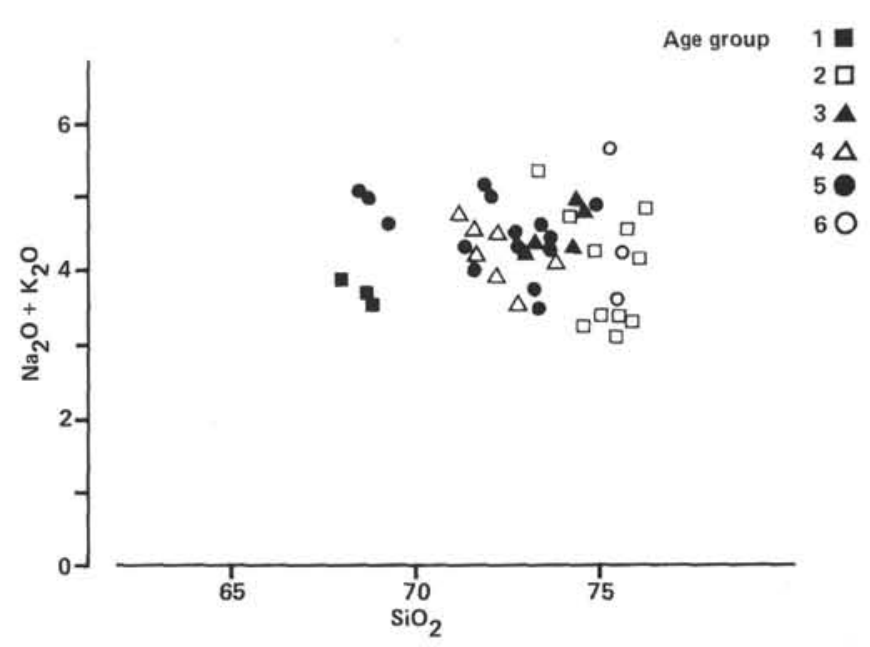

Figure 4. $\mathrm{SiO}_{2}$ /alkalinity diagram. Data are plotted by age group (see Table 2).

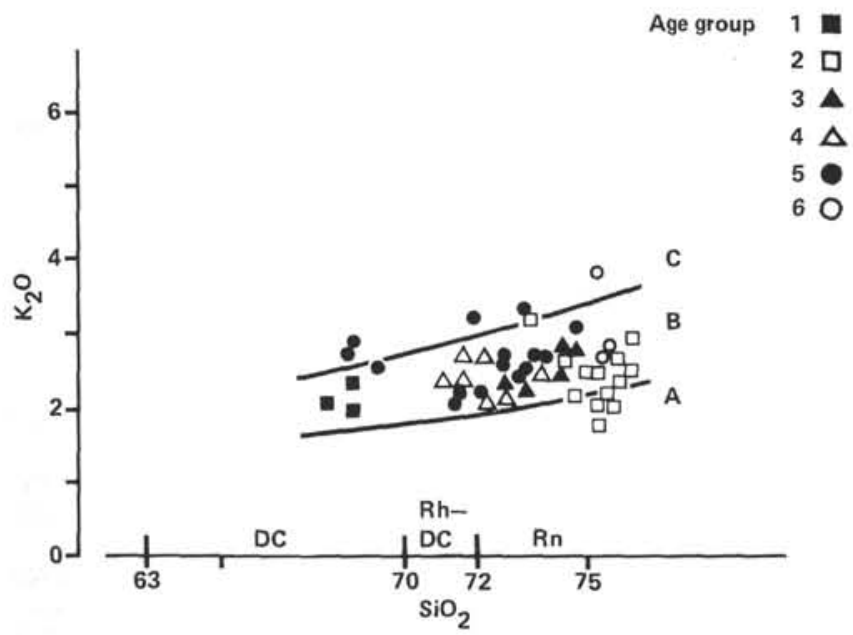

Figure 5. $\mathrm{SiO}_{2} / \mathrm{K}_{2} \mathrm{O}$ diagram. Data are plotted by age group (see Fig. 4 and Table 2$)$. $(\mathrm{DC}=$ dacite, $\mathrm{Rh}-\mathrm{DC}=$ rhyo-dacite, $\mathrm{Rh}=$ rhyolite. $\mathrm{A}=$ low-K, $\mathrm{B}=$ medium $\mathrm{K}, \mathrm{C}=$ high $\mathrm{K}$.)

\section{Limitations}

Even if this relatively simple method of recording explosive volcanism provides results complementary to those on land, where erosion destroys much evidence, it is limited by three main factors:

1) There exist only records of explosive silicic volcanism carried to the site by the prevailing winds, and the direction of these can vary with time.

2) Sedimentary environment plays an important part (sedimentation rate, slumping erosion on the slope, bioturbations). It seems that disseminated glasses would give a better picture of explosive volcanism than ash layers, owing to bioturbation and bad core recovery in the latter. Arthur et al. (1980) have shown that although the pattern of concentration of disseminated glass in the Japan Trench transect (Leg 57) is roughly similar to that of ash layer frequency, it depends greatly on the influx of clastic detritus and of the depositional environment, particularly at slope sites.
3) Alteration and diagenesis: Hein and Scholl (1978) stress that diagenesis reduces the number of ash layers (ash beds that have been transformed in smectitic clay minerals and zeolites are subsequently difficult to recognize by visual inspection). Owing to the lack of data we could not take diagenesis into account in calculating the number of ash layers.

Despite these limitations, our method gives patterns of volcanicity quite consonant with other data available in well-studied regions, such as the northwestern United States and its offshore sedimentary basins (Kennett et al., 1977), and offers a means by which the record of volcanism in one region can be correlated with that of another.

\section{Pattern of Explosive Volcanic Activity}

On Figure 9, we have grouped data corresponding to continental and upper slope sites $(493,489,490)$, slope sites $(492,491,488)$, and the oceanic site (487). The histograms traced from data from continental and upper slopes sites show that volcanic activity rises regularly to a peak between 17 and $16 \mathrm{Ma}$ in the early Miocene and then decreases. From $7 \mathrm{Ma}$ activity resumes moderately during the Pliocene, with a peak between 4 and 2 $\mathrm{Ma}$, decreases between 2 and $1 \mathrm{Ma}$, and shows a steep increase during the last million years. Slope sites record a moderate but continuous activity starting $10 \mathrm{Ma}$, with two pulses between 10 and 8 and 6 and $2 \mathrm{Ma}$. The oceanic site shows two sporadic pulses at 9 to 8 and 6 to $4 \mathrm{Ma}$ and a strong renewal beginning $2 \mathrm{Ma}$.

In short, the diagram points out two stages of high volcanic activity, an early one at about 18 to $15 \mathrm{Ma}$ and a late one during the Quaternary, with two less important episodes in the late Miocene and Pliocene (middle Miocene activity is unknown because of sedimentary hiatus).

\section{DISCUSSION}

Data for each site have unequal value and rest on relatively scarce ash layers and variable recovery. Early Miocene pulse activity is found in two sites close to the continent, with some differences between 16 and $18 \mathrm{Ma}$ BP owing to bad recovery and sedimentation environment (muddy silt at Site 489). There is no trace of this pulse in the other sites, which terminate at the upper Miocene.

The period of activity beginning in the late Miocene appears roughly continuous from one site to another, with fairly good correlations between slope and oceanic sites (number of ash layers is of secondary importance because of distance from volcanic sources). We specially note that (1) at Sites 492 and 487 some ash layers show discrete pulses in the late Miocene (10-8 Ma), and (2) at all sites, but with variable translation owing to sedimentary environment or recovery, there is a latest Miocene-Pliocene pulses and Quaternary increase of explosive volcanism, even in the oceanic site moving toward the volcanic sources (Ninkovich and Donn, 1976).

Despite the very scarce number of ash layers, which severely limit our conclusions, we detect from Leg 66 data, and with minor discrepancies, the main pulses of 


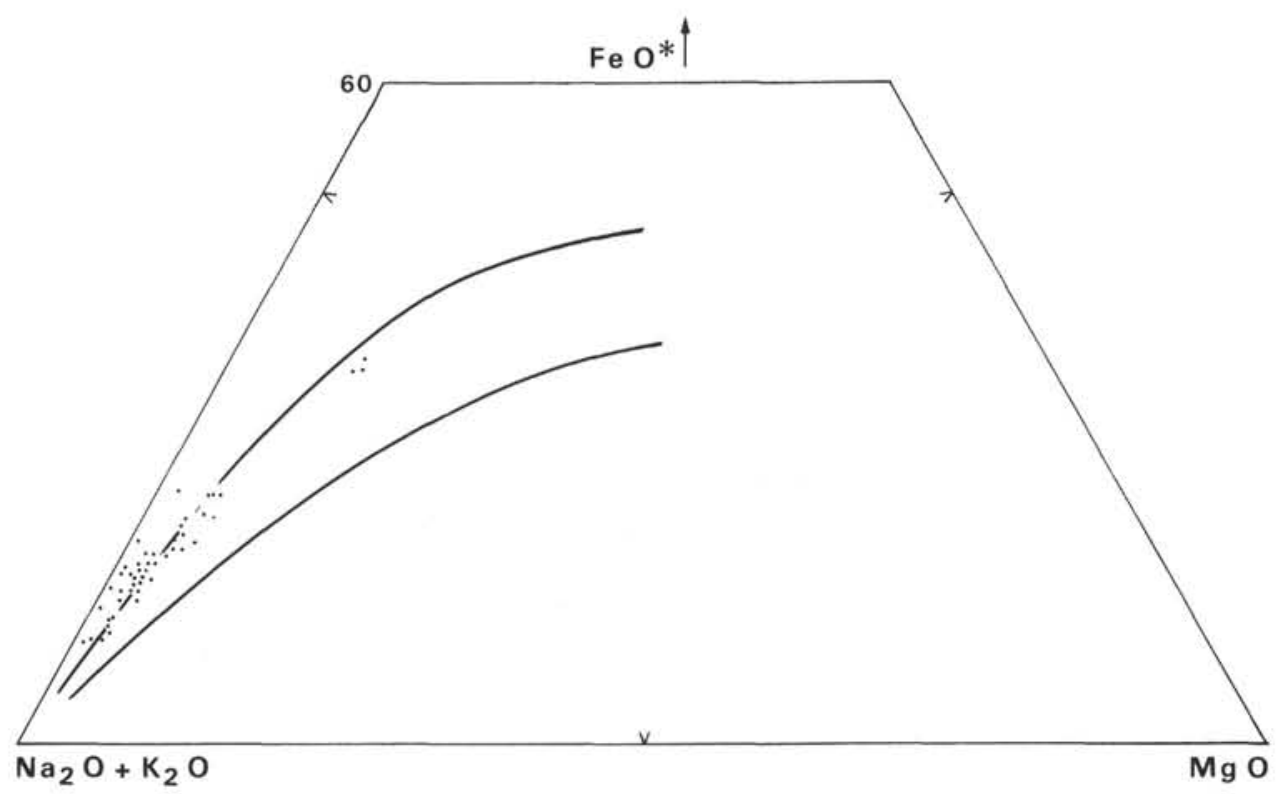

Figure 6. $\mathrm{FeO}^{*}-\left(\mathrm{Na}_{2} \mathrm{O}+\mathrm{K}_{2} \mathrm{O}\right)-\mathrm{MgO}$ diagram of volcanic glass. $\mathrm{FeO} *$ represents total iron calculated as FeO. The calc-alkaline trend of Peru (Bardintzeff et al., 1980) is shown as solid lines.

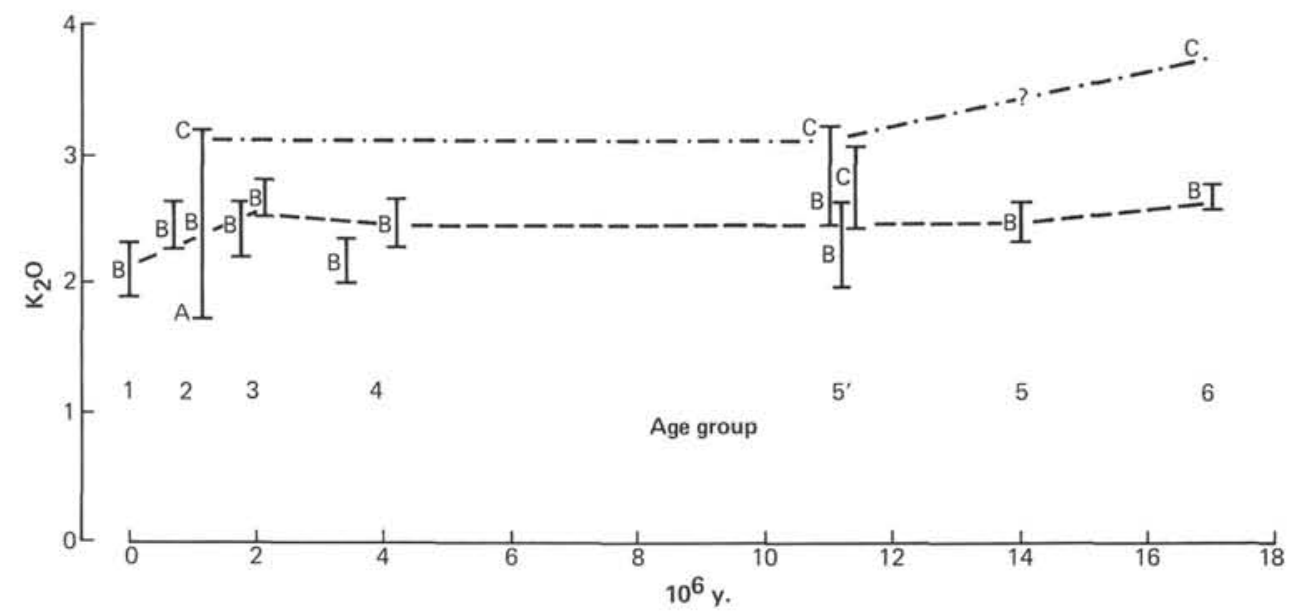

Figure 7. Diagram $\mathrm{K}_{2} \mathrm{O}$ /age group; chronological distribution of $\mathrm{A}, \mathrm{B}$, and $\mathrm{C}$ series.

Neogene volcanism detected in Central America from deep sea sedimentary sequences by Kennett et al. (1977) (Quaternary, $2 \mathrm{Ma}$ to Present; early to middle Pliocene, 5-3 Ma; late Miocene 10-8 Ma). We also demonstrate an early Miocene, 20 to $15 \mathrm{Ma}$ pulse, well documented on land but not yet recorded in DSDP cores in the Pacific off Central America.

\section{CONCLUSION}

These data conform to general trends in the circum Pacific where episodes of intense volcanism were separated by less active intervals. There are at least two major pulses of Neogene volcanism during the early Miocene and Quaternary and less distinct pulses during the Pliocene and late Miocene. This apparent synchronism of Cenozoic volcanic activity in the Pacific
(Kennett and Thunnel, 1975) indicates global rather than regional control. Several authors suggested that these episodes of volcanic activity associated with convergent boundary volcanism and mid-plate volcanism may reflect changing spreading-subduction rates. Increased subduction rates probably result in increased shear heating along the top of the slab and in an increased supply of water to the melting zone that may increase explosive volcanic activity; recent investigations (Rea and Scheidegger, 1979) in subduction zones and mid-plate in the Pacific seem to support this hypothesis. Further discussion in the area requires an investigation into the history of explosive volcanism in Central America, taking into account land records and data from Leg 67 sites and subsequently correlating them with spreading rate variation of the Cocos and Nazca plates (Cadet and Pouclet, in preparation). 


\section{J. P. CADET ET AL.}

Table 4. Microprobe analysis of feldspars.

\begin{tabular}{|c|c|c|c|c|c|c|c|c|c|c|c|c|c|c|c|}
\hline \multirow{2}{*}{$\begin{array}{c}\text { Hole } \\
\text { Core/Section/ } \\
\text { Interval }(\mathrm{cm})\end{array}$} & \multirow{2}{*}{$\begin{array}{c}492 \mathrm{~A} \\
6-2 \\
119-120\end{array}$} & \multirow{2}{*}{$\begin{array}{c}491 \\
4-5 \\
12-13\end{array}$} & \multirow{2}{*}{\multicolumn{2}{|c|}{$\begin{array}{c}492 \mathrm{~A} \\
6-2 \\
119-120\end{array}$}} & \multirow{2}{*}{\multicolumn{2}{|c|}{$\begin{array}{c}491 \\
6-1 \\
95-96\end{array}$}} & \multirow{2}{*}{\multicolumn{2}{|c|}{$\begin{array}{c}491 \\
4-5 \\
12-13 \\
\end{array}$}} & \multirow{2}{*}{\multicolumn{4}{|c|}{$\begin{array}{l}490 \\
23-7 \\
106\end{array}$}} & \multicolumn{2}{|c|}{ 493B } & \multirow{2}{*}{$\begin{array}{c}492 \\
11-1 \\
45-46 \\
\end{array}$} \\
\hline & & & & & & & & & & & & & $\begin{array}{c}1-4 \\
19-21\end{array}$ & $\begin{array}{c}1-3 \\
132-134\end{array}$ & \\
\hline Age Group & 3 & 3 & \multicolumn{2}{|c|}{3} & \multicolumn{2}{|c|}{3} & \multicolumn{2}{|c|}{3} & \multicolumn{4}{|c|}{3} & 1 & 1 & 4 \\
\hline Number & 81 & 20 & 80 & 49 & 37 & 36 & 21 & 23 & 53 & 54 & 52 & 55 & 77 & 73 & 16 \\
\hline $\mathrm{SiO}_{2}$ & 64.55 & 62.93 & 67.81 & 66.81 & 66.13 & 61.80 & 60.42 & 61.64 & 60.89 & 59.64 & 59.53 & 58.85 & 58.52 & 56.18 & 45.68 \\
\hline $\mathrm{Al}_{2} \mathrm{O}_{3}$ & 18.40 & 18.19 & 19.91 & 19.40 & 20.18 & 22.59 & 23.43 & 24.44 & 24.64 & 24.91 & 25.12 & 25.55 & 25.99 & 27.86 & 34.64 \\
\hline $\mathrm{FeO}$ & - & 0.15 & 0.04 & 0.05 & 0.10 & 0.02 & 0.29 & - & 0.19 & 0.23 & 0.35 & 0.10 & 0.48 & 0.34 & 0.46 \\
\hline $\mathrm{CaO}$ & - & - & 0.33 & 0.23 & 0.03 & 4.20 & 5.18 & 5,48 & 6.38 & 6.51 & 7.10 & 7.40 & 8.31 & 10.22 & 18.21 \\
\hline $\mathrm{Na}_{2} \mathrm{O}$ & 0.22 & 1.18 & 10.22 & 11.25 & 11.71 & 8.59 & 8.25 & 8.45 & 7.45 & 7,40 & 6.90 & 6.95 & 6.37 & 5.62 & 1.05 \\
\hline $\mathrm{K}_{2} \mathrm{O}$ & 16.06 & 15.08 & 0.77 & 0.03 & 0.06 & 0.83 & 0.25 & 0.20 & 0.48 & 0.41 & 0.28 & 0.34 & 0.59 & 0.32 & 0.04 \\
\hline Total & 99.23 & 97.53 & 99.11 & 97.77 & 98.20 & 98.03 & 97.82 & 100.22 & 100.04 & 99.09 & 99.28 & 99.18 & 100.27 & 100.54 & 100.08 \\
\hline $\mathrm{Si}$ & 3.001 & 2.980 & 3.170 & 2.982 & 2.948 & 2.794 & 2.741 & 2.727 & 2.707 & 2.682 & 2.671 & 2.647 & 2.614 & 2.517 & 2.105 \\
\hline $\mathrm{Al}$, & 1.008 & 1.016 & 1.054 & 1.021 & 1.060 & 1.204 & 1.253 & 1.275 & 1.291 & 1.320 & 1.328 & 1.354 & 1.369 & 1.471 & 1.881 \\
\hline $\mathrm{Fe}^{+2}$ & - & 0.006 & 0.003 & 0.002 & 0.004 & 0.001 & 0.011 & - & 0.007 & 0.009 & 0.013 & 0.004 & 0.018 & 0.013 & 0.018 \\
\hline $\mathrm{Ca}$ & - & - & 0.023 & 0.011 & 0.001 & 0.203 & 0.252 & 0.260 & 0.304 & 0.314 & 0.342 & 0.356 & 0.398 & 0.491 & 0.899 \\
\hline $\mathrm{Na}$ & 0.020 & 0.108 & 0.758 & 0.974 & 1.012 & 0.753 & 0.725 & 0.725 & 0.642 & 0.645 & 0.600 & 0.606 & 0.552 & 0.489 & 0.094 \\
\hline $\mathrm{K}$ & 0.953 & 0.911 & 0.064 & 0.002 & 0.003 & 0.048 & 0.014 & 0.011 & 0.027 & 0.024 & 0.016 & 0.019 & 0.034 & 0.019 & 0.002 \\
\hline Or & 97.96 & 89.40 & 2.72 & 0.20 & 0.33 & 4.75 & 1.44 & 1.13 & 2.81 & 2.40 & 1.66 & 1.97 & 3.42 & 1.86 & 0.22 \\
\hline $\mathrm{Ab}$ & 2.04 & 10.60 & 89.71 & 98.69 & 99.54 & 74.99 & 73.14 & 72.77 & 65.97 & 65.67 & 62.68 & 61.74 & 56.13 & 48.95 & 9.45 \\
\hline An & - & - & 7.57 & 1.11 & 0.13 & 20.26 & 25.42 & 26.10 & 31.22 & 31.93 & 35.66 & 36.29 & 40.45 & 49.18 & 90.33 \\
\hline
\end{tabular}

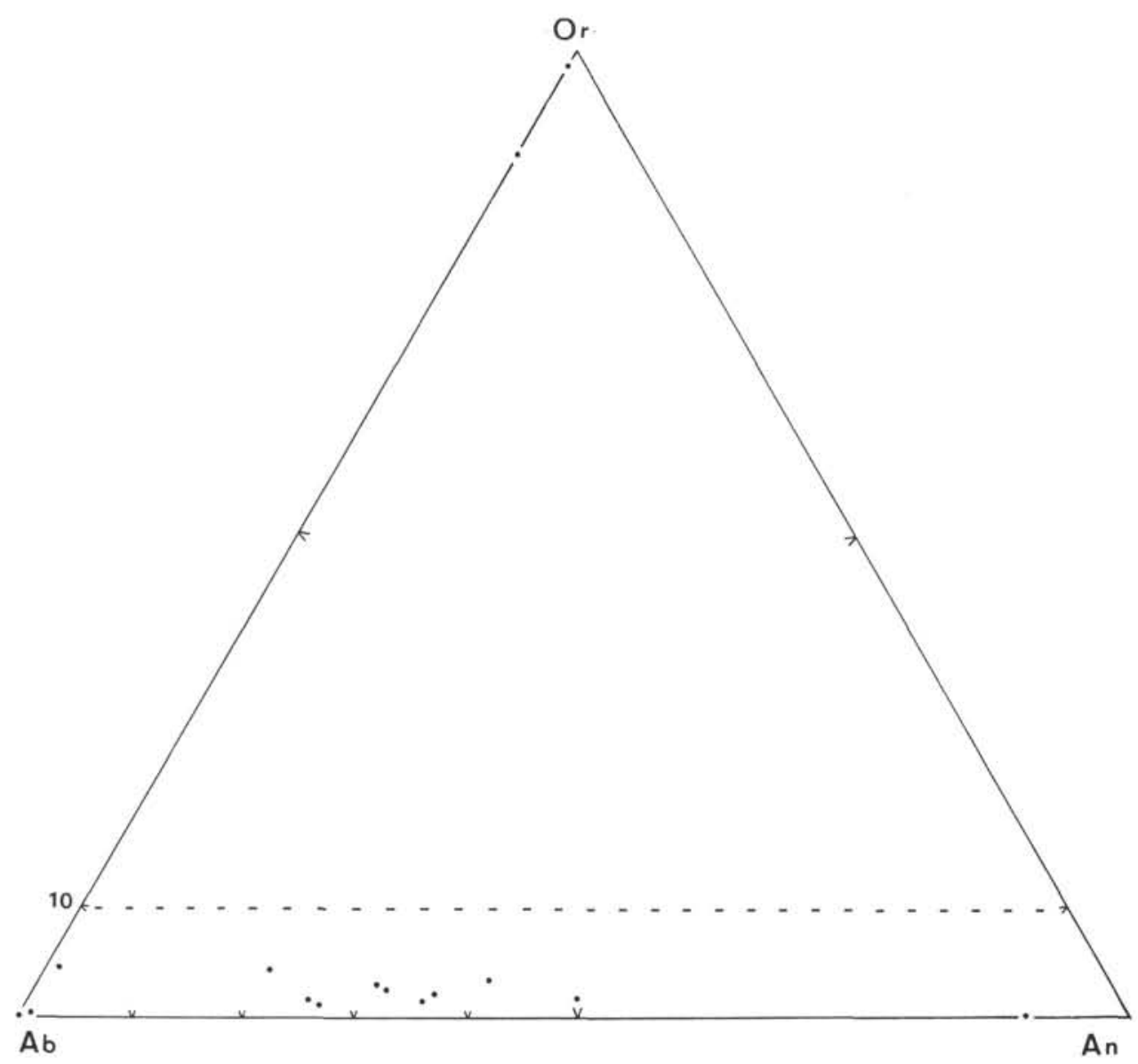

Figure 8. Or-Ab-An plot of feldspars.

\section{REFERENCES}

Arthur, M. A., von Huene, R., and Adelseck, C. G., 1980. Sedimentary evolution of the Japan fore-arc region off northern Honshu, Legs 56 and 57, Deep Sea Drilling Project. In Scientific Party, Init. Repts. DSDP, 56, 57, Pt. 1: Washington (U.S. Govt. Printing Office), 521-568.

Bardintzeff, J. M., Brousse, R., Clocchiati, R., et al., 1980. Évolution des phénocristaux et de leurs inclusions magmatiques dans la “dacite" du dôme du Santiaguito (Guatemala). C. R. Acad. Sci. Paris, 290-D:743-746.

Cadet, J. P., and Fujioka, K., 1980. Neogene volcanic ashes and explosive volcanism: Japan trench transect, Leg 57, DSDP. In Scientific Party, Init. Repts. DSDP, 56, 57, Pt. 2: Washington (U.S. Govt. Printing Office), 1027-1041.

Demant, A., 1978. Caracteristicas del Eje Neovolcanico Transmexicano y sus problemas de interpretacion. Rev. Inst. Geol. UNAM, 2 (2):172-187. 
Fujioka, K., Furuta, T., and Arai, F., 1980. Petrography and geochemistry of volcanic glass: Leg 57, DSDP. In Scientific Party, Init. Repts. DSDP, 56, 57, Pt. 2: Washington (U.S. Govt. Printing Office), 1049-1066.

Gastil, G., Krummenacher, D., and Minch, J., 1979. The records of Cenozoic volcanism around the Gulf of California. Geol. Soc. Am. Bull., 90:839-857.

Hein, J. R., and Scholl, D. W., 1978. Diagenesis and distribution of late Cenozoic volcanic sediment in the southern Bering sea. Geol. Soc. Am. Bull., 89:197-210.

Hein, J. R., Scholl, D. W., and Miller, J., 1978. Episodes of Aleutian Ridge explosive volcanism. Science, 199:137-141.

Kennett, J. P., McBirney, A. R., and Thunell, R. C., 1977. Episodes of Cenozoic volcanism in the circum-Pacific region. J. Volcanol. Geotherm. Res., 2:145-163.

Kennett, J. P., and Thunell, R. C., 1975. Global increase in Quaternary explosive volcanism. Science, 187:497-503.

McDowell, F. W., and Clabaugh, S. E., 1979. Ignimbrites of the Sierra Madre Occidental and their relation to the tectonic history of Western Mexico. Spec. Pap. Geol. Soc. Am., 180:113-124.

Moore, J. C., Watkins, J. S., Bachman, S. B., et al., 1979a. Off Mexico Middle America Trench. Geotimes, 24:20-22.

, 1979b. Progressive accretion in the Middle America Trench, Southern Mexico. Nature, 281:638-642.

Ninkovich, D., and Donn, W. L., 1976. Explosive Cenozoic volcanism and climatic implications. Science, 194:899-906.

Pecerillo, A., and Taylor, S. R., 1976. Geochemistry of Eocene calcalkaline volcanic rocks from the Kastamou area, Northern Turkey. Contrib. Mineral. Petrol., 58:63-81.

Rea, D. K., and Scheidegger, K. F., 1979. Eastern Pacific spreading rate fluctuation and its relation to Pacific area volcanic episodes. J. Volcanol. Geotherm. Res., 5:135-148.

Scheidegger, K. F., Jezek, P. A., and Ninkovich, D., 1978. Chemical and optical studies of glass shards in Pleistocene and Pliocene ash layers from DSDP Site 192, northwest Pacific Ocean. J. Volcanol. Geotherm. Res., 4:99-116.

Thornton, C. P., and Tuttle, O. F., 1960. Chemistry of igneous rocks. I: Differentiation index. Am. J. Sci., 258:664-684.

Table 5. Microprobe analysis of amphiboles, Sample 489A-1,CC.

\begin{tabular}{lrr}
\hline \multicolumn{1}{r}{ No. } & \multicolumn{1}{r}{42} & \multicolumn{1}{c}{43} \\
\hline $\mathrm{SiO}_{2}$ & 44.33 & 44.09 \\
$\mathrm{Al}_{2} \mathrm{O}_{3}$ & 10.27 & 10.36 \\
$\mathrm{TiO}_{2}$ & 1.19 & 1.40 \\
$\mathrm{FeO}$ & 16.18 & 15.98 \\
$\mathrm{MnO}$ & 0.45 & 0.61 \\
$\mathrm{MgO}$ & 11.22 & 10.75 \\
$\mathrm{Cr} \mathrm{O}_{3}$ & 0.02 & 0.00 \\
$\mathrm{CaO}$ & 11.61 & 11.64 \\
$\mathrm{Na}_{2} \mathrm{O}$ & 1.01 & 1.10 \\
$\mathrm{~K}_{2} \mathrm{O}$ & 0.83 & 0.80 \\
$\mathrm{H}_{2} \mathrm{O}$ & 2.00 & 1.99 \\
$\mathrm{Total}$ & 99.09 & 98.73 \\
$\mathrm{Si}$ & 6.655 & 6.647 \\
$\mathrm{Al}$ & 1.817 & 1.841 \\
$\mathrm{Ti}$ & 0.134 & 0.159 \\
$\mathrm{Fe}$ & 2.031 & 2.014 \\
$\mathrm{Mn}$ & 0.057 & 0.078 \\
$\mathrm{Mg}$ & 2.510 & 2.416 \\
$\mathrm{Cr}$ & 0.002 & 0.000 \\
$\mathrm{Ca}$ & 1.868 & 1.880 \\
$\mathrm{Na}$ & 0.293 & 0.322 \\
$\mathrm{~K}$ & 0.158 & 0.154 \\
$\mathrm{OH}$ & 1.000 & 1.000 \\
$\mathrm{Total}$ & 16.526 & 16.511 \\
$100 \mathrm{Mg} /$ & 56.59 & 53.59 \\
$\mathrm{Mg}+\mathrm{Fe}+\mathrm{Mn}$ & & \\
\hline & &
\end{tabular}


Number of Ash Layers
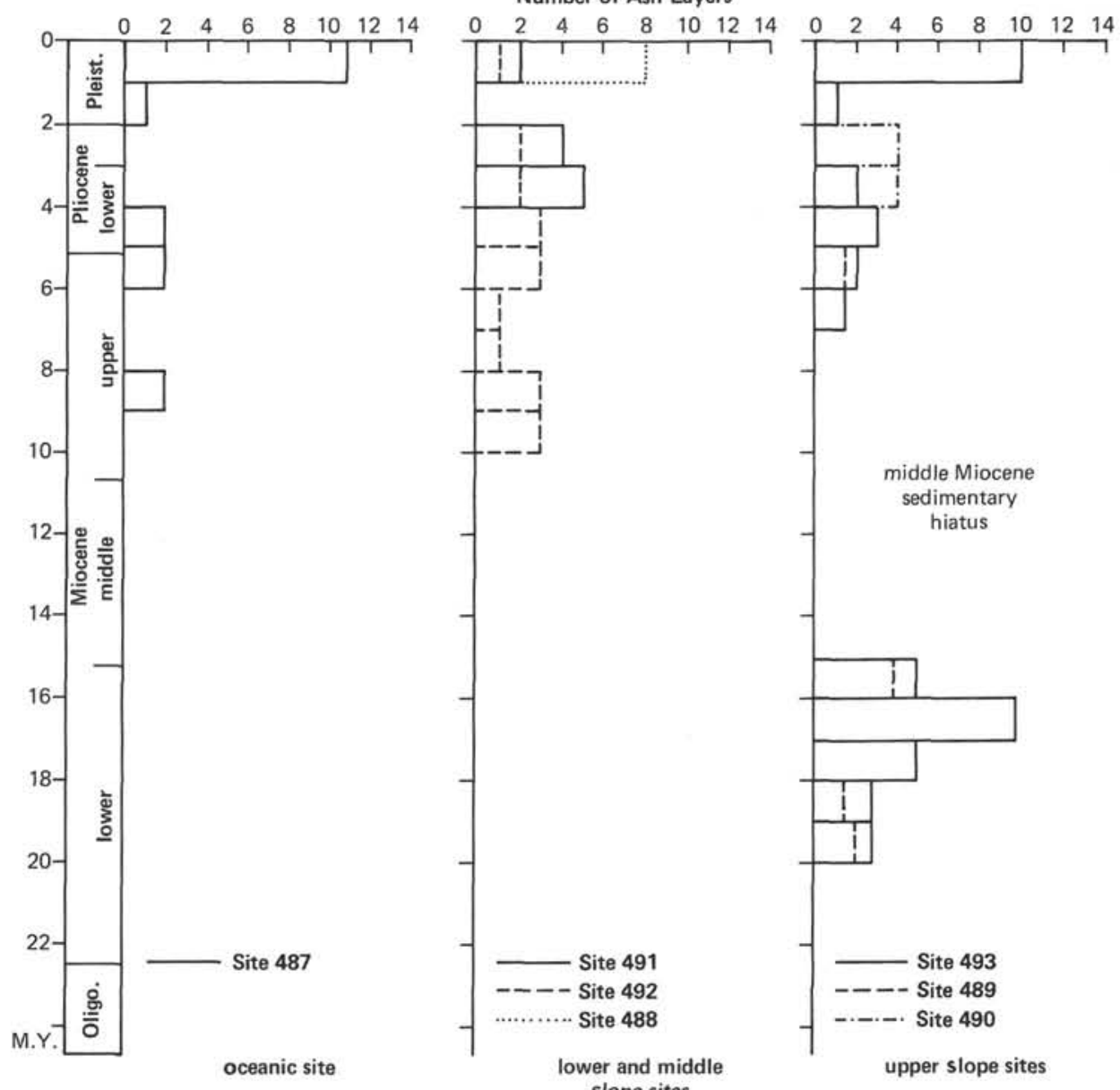

Figure 9. Periods of explosive volcanism in the Middle America Trench (Leg 66 area) as recorded by ash beds (data are plotted at a uniform $1.0 \times 10^{6} \mathrm{y}$. interval with correction for core recovery). 

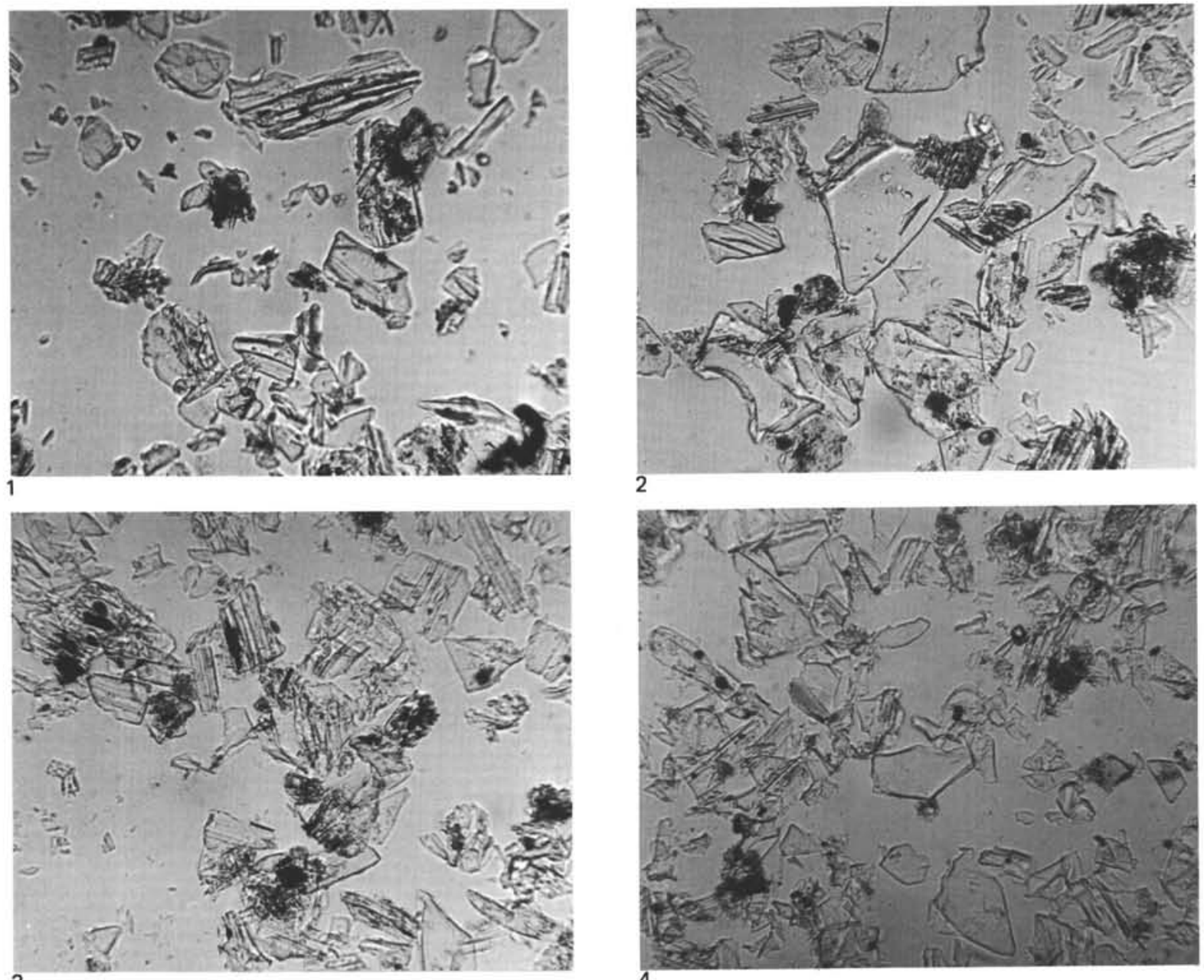

2

3
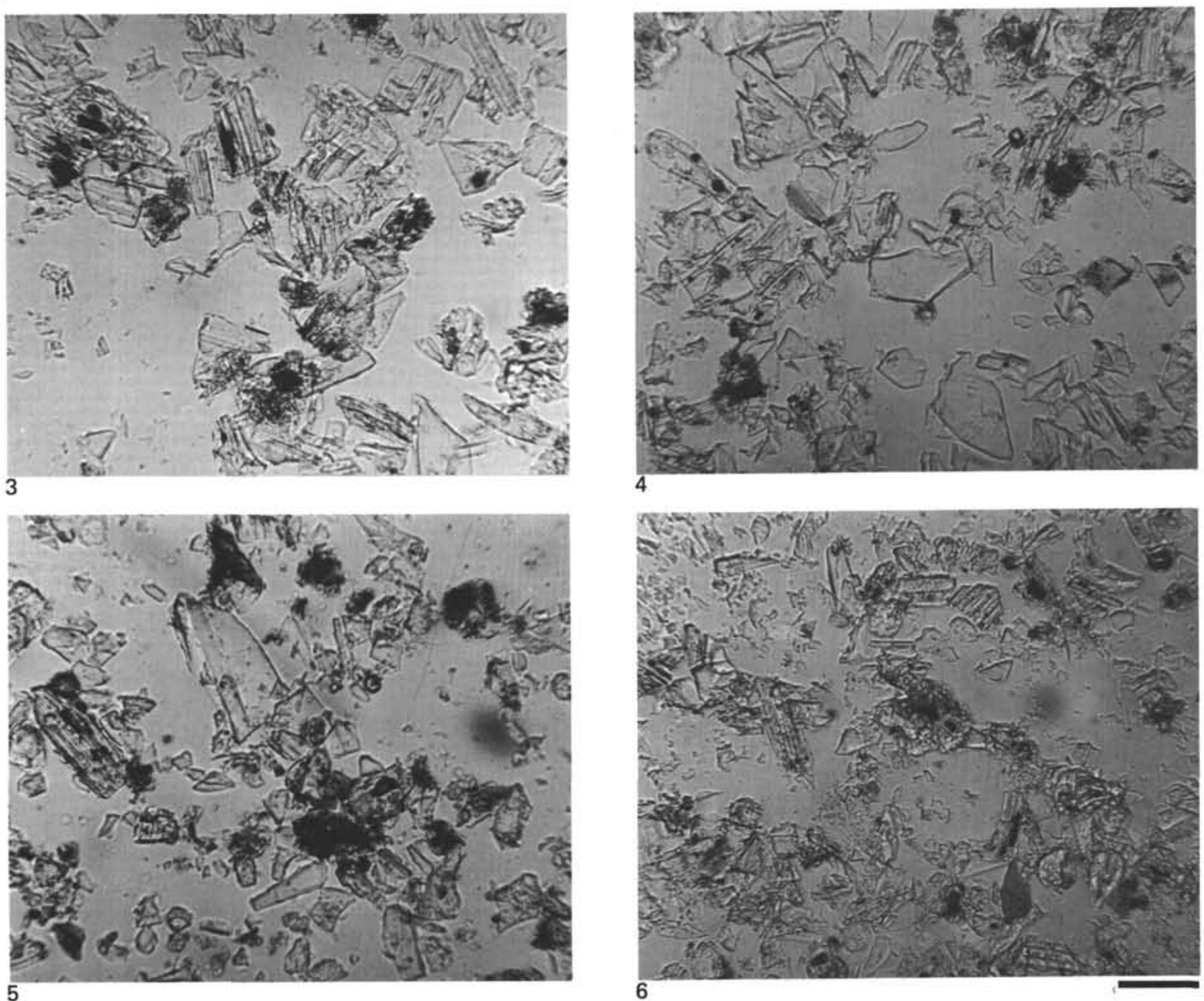

Plate 1. Smear slides of volcanic ashes (scale bar $=100 \mu \mathrm{m} ; \times 125$ ). 1. Clear shards and shards with tubular vesicles and brown clay. Quaternary, Sample 491-4-5, $12 \mathrm{~cm}$. 2. Essentially clear angular and smooth glass shards. (Note pumice fragment). Quaternary, Sample 491-4-5, 12 cm. 3. Shards with tubular vesicles and some angular fragments. Upper Miocene, Sample $492-16-4,0 \mathrm{~cm}$. 4. Mixture of volcanic ash with clear, flattened shards. Upper Miocene, Sample 492-21-2, $49 \mathrm{~cm}$. 5. Platy glasses and tubular pumices. Lower Pliocene, Sample 492A-6-2, 119 cm. 6. Mixture of volcanic ash with small, clear shards and shards with tubular vesicles (note brown basaltic glass in the lower part). Early Miocene, Sample 489A-9-2, $84 \mathrm{~cm}$. 

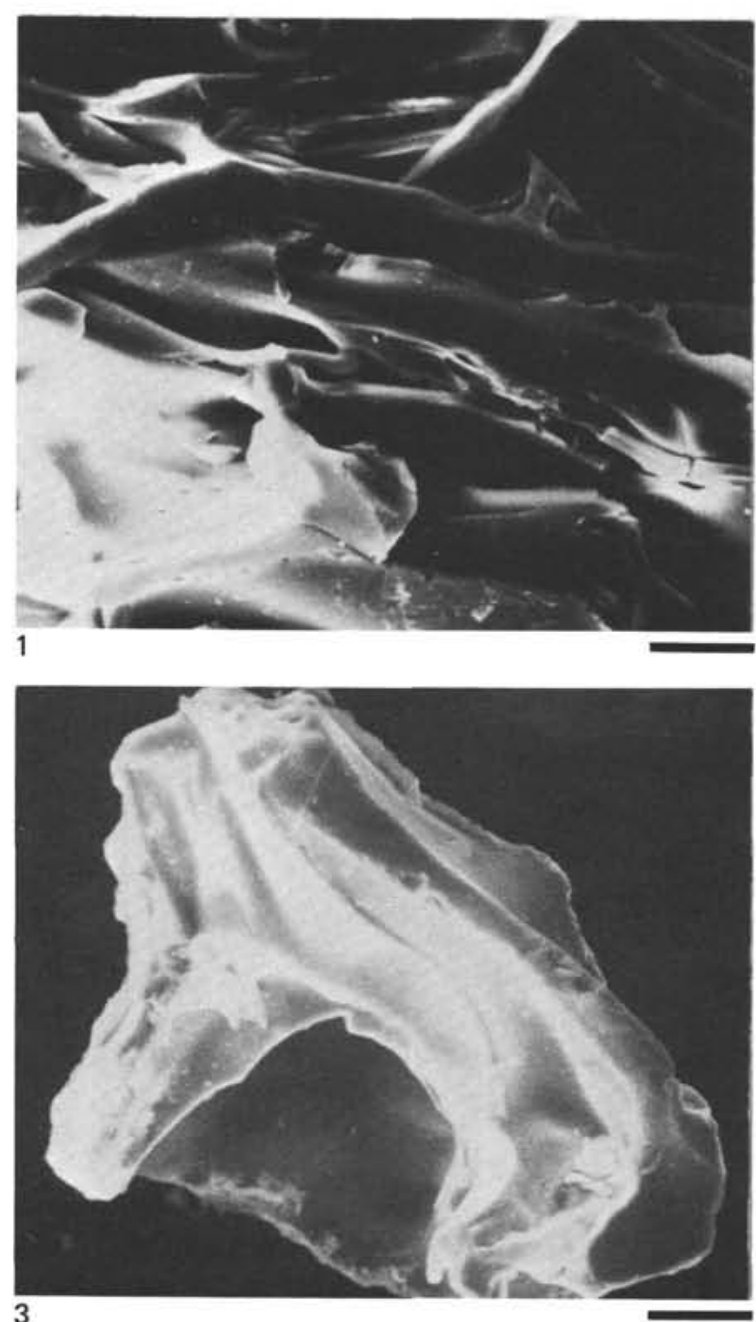

3

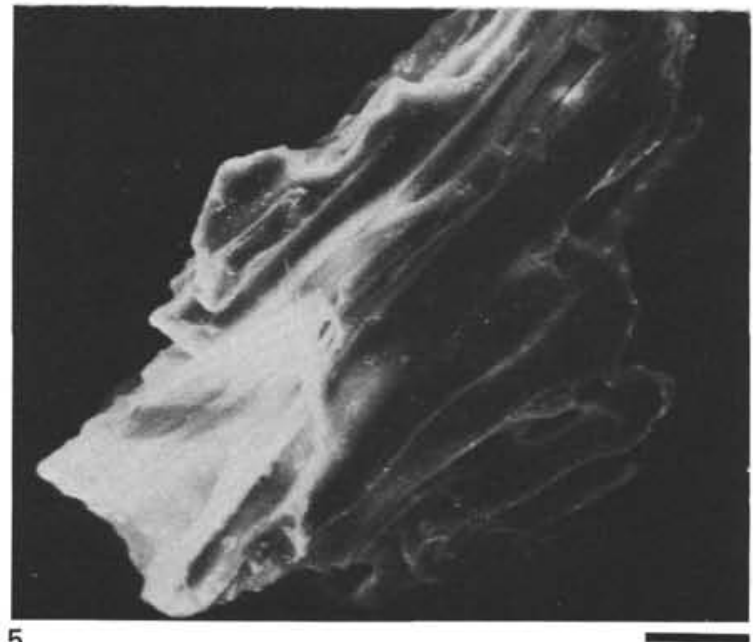

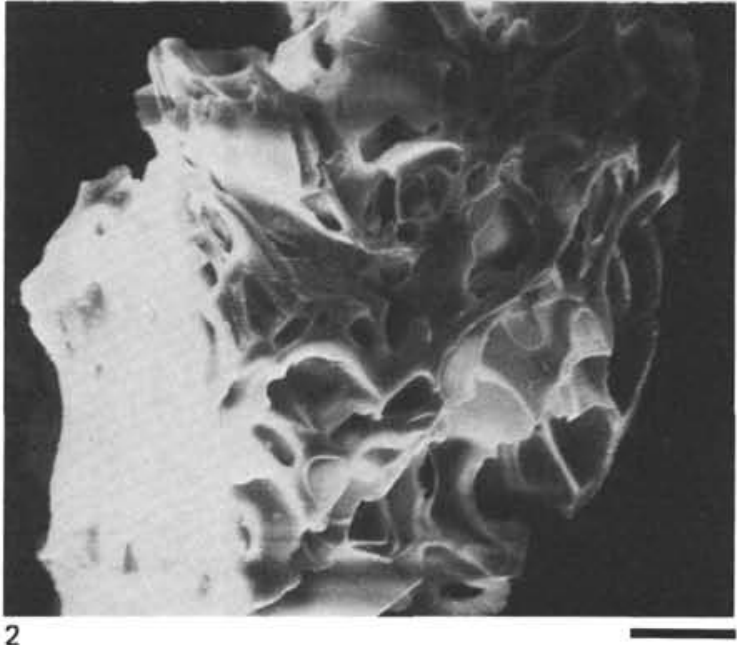

2

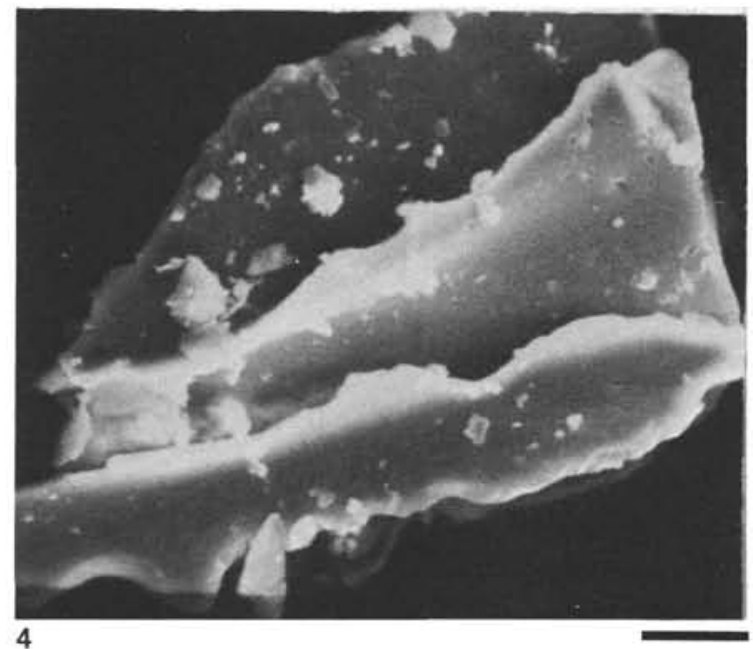

4

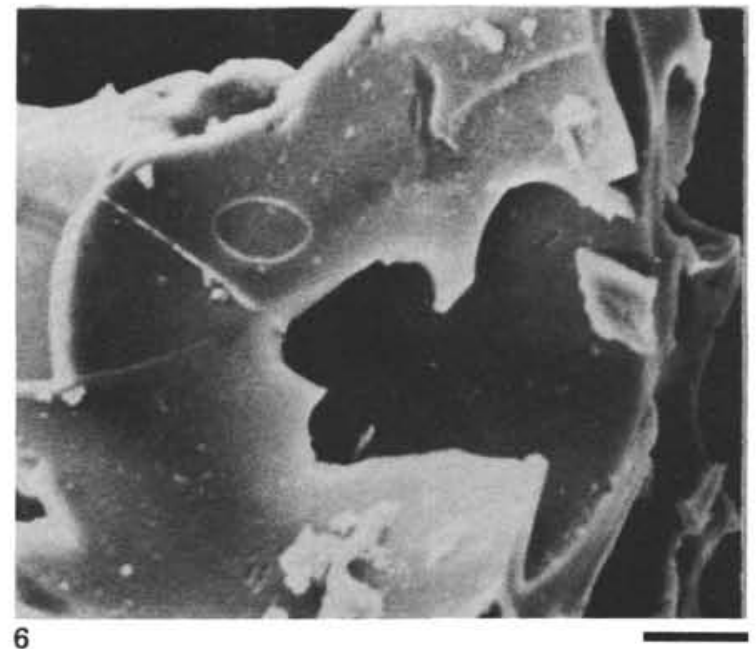

6

Plate 2. Scanning electron microscope photographs of volcanic glasses (scale bar $=15 \mu \mathrm{m}$ ). 1. Detail of a glass fragment with tubular vesicles $(\times 800)$. Middle Pliocene, Sample 493-9-2, $140 \mathrm{~cm}$. 2. Bubble glass with a lot of ovoid vesicles $(\times 800)$. Middle Pliocene, Sample 493-9-2, 140 cm. 3. Bubble glass $(\times 400)$. Middle Pliocene, Sample $493-9-2,140 \mathrm{~cm}$. 4. Elongated glass shard $(\times 800)$. Quaternary, Sample $487-6, C \mathrm{C}, 12$ $\mathrm{cm}$. 5. Glass shard with tubular and parallel vesicles $(\times 800)$. Quaternary, Sample $491-4-5,12 \mathrm{~cm}$. 6. Detail of a broken ovoid vesicle $(\times 800)$. Early Miocene, Sample 489-2-6, $114 \mathrm{~cm}$. 